\title{
Investigation of processes of rocks deformation and the earth's surface subsidence during underground coal mining
}

\author{
Volodymyr Buzylo ${ }^{1}$, Artem Pavlychenko ${ }^{2 *}$, Olena Borysovska $^{2}$ and Dmytro Saveliev ${ }^{3}$ \\ ${ }^{1}$ Dnipro University of Technology, Department of Underground Mining, 19 Yavornytskoho Ave., \\ 49005 Dnipro, Ukraine \\ ${ }^{2}$ Dnipro University of Technology, Department of Ecology and Environmental Protection \\ Technologies, 19 Yavornytskoho Ave., 49005 Dnipro, Ukraine \\ ${ }^{3}$ Dnipro University of Technology, Department of Labour Protection and Civil Security, \\ 19 Yavornytskoho Ave., 49005 Dnipro, Ukraine
}

\begin{abstract}
Many years of coal production have led to significant changes in the stability of the rock mass and the earth's surface in the territory of the coal mining regions of Ukraine. The reasons for such changes are the increase of fracture and decrease of the strength of rocks, stratification and hanging of rocks in the boundary parts of workings, the presence of interstices in the coal-face workings, large-scale subsidence of the earth's surface, underworking of a considerable number of buildings, structures and infrastructure.
\end{abstract}

\section{Introduction}

In the global economy, coal plays an important role among natural energy resources and occupies the third position in terms of use after oil and natural gas. The coal industry is an important component of the industrial potential of Ukraine and it ensures the functioning of leading sectors of the economy [ $1-3]$. The sustainable development of the state, its energy and environmental safety depend on the effectiveness and stability of its functioning [4-6].

The problem of environmental protection in Ukraine is of crucial importance [7-9]. Mining enterprises cause significant environmental, social and economic damage to the country's economy, as they are powerful sources of pollution and transformation of the environmental components of industrial regions [10 - 14].

During underground mining of coal deposits, the main factors that significantly worsen the environmental situation of coal-mining regions are: undermining and deformation of the earth's surface, the release of large volumes of rock from mines [13-15], pollution of water and air basins [16 - 21], the formation of significant amounts of waste, alienation and pollution of land resources, as well as the negative impact on living organisms and human health $[22-24]$.

The rock given out from the mines occupies large areas of land suitable for agriculture. At the same time, about $40 \%$ of surface and underground transport and more than $30 \%$ of

* Corresponding author: pavlichenko.a.v@nmu.one 
transport workers are used to produce the rock winding [25 - 27]. A significant part of the rock is transported and delivered to the surface via coal transport lines, thereby causing a significant contamination of coal by the rock and, consequently, a sharp decrease in its quality [28 - 32].

It should be noted that coal mining, including from pillars, negatively affects the environmental state of the daylight surface due to displacement and deformation of rocks. Dips, deflections, troughs of displacement, etc. are formed on the surface. The problem of undermining the earth's surface is the most relevant for the mines of the Western Donbas. This is due to the fact that in this region $[5,13,14,19]$ :

- Mining and geological conditions are difficult. The rocks that contain coal seams are characterized by low mechanical strength, a tendency to soak, delaminate and swell. To this view, subsidence of the earth's surface as a result of coal seams mining is $90-95 \%$ of their removable capacity;

- Hydrogeological conditions are complex. In the territory of the Western Donbas, more than ten aquifers and complexes in sedimentary crystalline rocks are distinguished. The groundwater level in the floodplain of the Samara River is slightly higher than the maximum water level in the river $(0.5-1.5 \mathrm{~m})$;

- A characteristic feature of the Western Donbass is the location of a significant part of the coal reserves under the floodplain of the Samara River and its tributaries. Among 10 operating mines, 8 are developing reserves under the floodplain. The balance reserves within the boundaries of the zones of underground operations influence on the protected surface objects of existing mines account for more than $40 \%$ of the total balance reserves;

- In the mines of the Western Donbas, about $40 \%$ of the rock of the total amount of mined coal is exposed to the surface.

Improving the ecological state of the West Donbas requires solving two main issues: reducing the volume of rock discharged from the mines and reducing the deformations of the surface that arise as a result of mining operations [33-37].

From an analysis of scientific works and literary sources, it can be stated that the issue of creating environmental protection, low-waste technology for the conditions of the Western Donbas remains insufficiently unresolved, although some work in this direction has been carried out.

\section{The research problem setting}

During underground mining of coal seams, displacements and deformations of rocks occur. These displacements cause significant changes in the field of gravitational forces with the formation of support zones in which the stresses are several times higher than the stresses of the untouched mass [33-38]. Changes in the rock mass, depending on natural, mining, and production factors, lead to significant difficulties in conducting coal-face works [3741]. The harmful effect of abutment pressure is manifested not only in the plane of the seam, but also in the rocks at a considerable distance from it up to the earth's surface.

In the conditions of the mines of the Western Donbas, where the coal-bearing stratum is composed of unstable rocks [ 41 - 43], subsidence of the earth's surface reaches up to $95 \%$ of the removed thickness of the seams. The number of coal seams of working thickness at each mine is different and varies from 4 to 11 . The total thickness in this case is $3.5-9.0 \mathrm{~m}$. When mining all coal seams according to the currently generally accepted technology and the method of managing the roof completely caving, subsidence of the earth's surface can reach $3-8 \mathrm{~m}$. Such subsidence of the earth's surface contributes to the violation of the ecological state of coal-mining regions.

Particularly acute for the Western Donbas is the problem of maintaining the ecological balance and the introduction of resource-saving technologies. A characteristic feature of 
this region is the location of a significant part of the coal reserves under the floodplain of the Samara River and its tributaries. The width of the floodplain reaches $4 \mathrm{~km}$. The surface of the floodplain is horizontal, has a slight excess $(1-2 \mathrm{~m})$ above the river level during the low-water period. Underground mining of coal seams leads to waterlogging and flooding of the surface with settlements, industrial facilities, communications, agricultural land and forests located on it. The situation is aggravated by the fact that the arched stratum of rocks in the Western Donbas is composed of low-metamorphosed sandy-clay rocks, which are characterized by weak strength and low stability [43 - 47].

To establish the patterns of formation of rock pressure during the development of gently dipping coal seams and assess its impact on the earth's surface, it is necessary

- To conduct mine observations to establish the dependences of the subsidence of the roof rocks on the accepted practice and its parameters;

- To monitor the subsidence of the earth's surface in the areas of underworking and to establish its dependence on the time parameters of coal-face works;

- To develop a calculation model to determine the stress-strain state of the rock mass and to forecast subsidence of the earth's surface during its underworking on the basis of experimental data;

- To develop a methodology for determining the rational parameters of the coal-face works when mining gently dipping coal seams, taking into account deformations of the earth's surface;

- To develop recommendations on the parameters of the coal-face works for the mines of the Western Donbas.

\section{Analysis of the nature, patterns and values of the parameters of rock pressure manifestation}

Mining operations in the conditions of underground mining of minerals provokes geomechanical processes in a structurally heterogeneous rock mass [43-47]. At the same time, the underworked rock stratum is shifted and its physicochemical properties change. With significant size of the underworking area, the movement of rocks reaches the earth's surface. The main coal mining areas are located on the territory of densely populated, industrialized regions with a high building density. Therefore, currently there is less and less space on which mining can be carried out without taking into account deformations of the earth's surface.

The main aim of the studies is to establish the nature, patterns and values of the parameters of the rock pressure manifestation in long breakage faces and in chambers during mining of coal seams in specific mining and geological conditions.

The object of research was a structurally heterogeneous rock mass, including coal seams, during underground coal mining in specific mining-geological and mining-technical conditions. The breakage faces and face entries selected for the research were representative, since they included all the existing mining-geological and mining-technical conditions for mining seams in the Western Donbas.

Mine research was carried out in the existing wall faces and face entries of the "Pavlohradska", "Yuvileina", "Stepova", "Blahodatna", and "Zakhidno-Donbaska" mines in accordance with the provisions of the working methodology.

In all the wall faces, the coal seams were mined according to the pillar mining system, the lengths of the extraction pillars were usually $1.1-1.2 \mathrm{~m}$, the lengths of the wall faces were $180-200 \mathrm{~m}$. Pillars are mined mainly to the rise, less often to the dip and to the strike. At the "Stepova" mine, all wall faces are equipped with KMK-97M complexes with MK-98 powered support and MK-67M combine, at the remaining mines, studies were conducted in wall faces equipped with KD-80 or KD-90 complexes with KA-80 combines 
or two $1 \mathrm{~K} 101 \mathrm{U}$ combines.

Mine research was carried out in accordance with the provisions of a specially developed working methodology that meets the requirements of existing methods and standards.

In the study of mining-geological and mining-technical indicators of coal seam mining in conditions of a specific working face were studied in detail:

- Thickness and angle of incidence of the seam, their fluctuations; exploitation depth; hypsometry of the roof and soil along the length of the wall face;

- The composition, structure and physical and mechanical properties of the seam and lateral rocks, their fracturing; volume of gas, abundance of water and dust formation;

- Characteristics of the coal-face working and excavation workings contouring it, coal extraction technology.

The study of these indicators was carried out according to mine documentation, and by direct observation and measurement.

When observing the state, stability, and movement of the lateral rocks in the working area of the wall face, special attention was paid to cracks, cutter breaks, cuts, shortening of the roof and inrushes, the moment of occurrence of faults in roof was recorded, it was noted at what distance from the face it appeared. In this case, the width of the cracks and the displacement of the rocks along them were measured. The nature of deformations and caving of rocks, clod content, thickness of collapsing rocks, the sequence of collapses, the influence of roof faults in the working area on the nature of its caving were studied.

Measurements of the values and rates of closure of the lateral rocks were carried out during the extraction of coal, the movement of the supports and the absence of production processes. In this case, zones of influence of production processes on the magnitude and rate of convergence of lateral rocks were determined. The coal seams in all the studied wall faces are gently dipping (incidence angle $\left.3-5^{\circ}\right)$, thin $(m=0.7-1.05)$, the useful worked thickness varied within $1.0-1.1 \mathrm{~m}$. In the process of mining the extraction pillars, characteristic tectonic disturbance was often observed. Crushing zones up to $10 \mathrm{~m}$ accompanied faults on both sides of the displacer with a sharp decrease in the strength properties of coal and enclosing rocks. Zones of inelastic deformations were formed above the arches and along the sides of the development workings, within which the roof rocks were very unstable. When working in the zones of faults, in the working area of the wall face after the passage of the combine, roof rocks inrushes of height from 0.5 to $1.2 \mathrm{~m}$ and along the length of the wall face $-5-8 \mathrm{~m}$ were observed. Near tectonic faults, the inrushes reached a height of $2.0-2.5 \mathrm{~m}$. All coal seams have natural moisture. The coal seams are dangerous for the explosiveness of coal dust and methane gas, but not prone to spontaneous combustion. Natural gas content in the area of wall faces was $5.0-14.5 \mathrm{~m}^{3} / \mathrm{t}$ of daily production. The rocks of the immediate roof were represented by unstable argillites, rarely - aleurolites. The soil rocks were composed of argillites or aleurolites of medium stability. The natural fracturing of the roof rocks was $4-5$ cracks per meter, sometimes $10-12$ cracks per meter.

Crack formation was studied visually, and the crack opening width was measured with a ruler. During the study, the intensity of crack formation was $6-8$ cracks per 1 linear meter along the wall face, and at its end sections (up to $5 \mathrm{~m}$ ) it was $10-12$ cracks per 1 linear meter. Increased fracturing of the rocks $(12-15$ cracks) was noted around the extraction galleries.

In the wall faces, in the presence of unstable argillites in the immediate roof, the process of crack formation occurred as follows: after the excavation of the seam by the combine, a vertical technological crack appeared in the roof parallel to the face line. This crack opened slightly $(3-5 \mathrm{~mm})$. But the subsidence of the roof rocks along this crack occurred and reached $15-25 \mathrm{~mm}$ - see Figs. 1a and 2a). After the extraction of the next strip of coal (the working width of the combine is $0.8 \mathrm{~m}$ ), the crack opened up to a width of $10 \mathrm{~mm}$. In the 
vicinity of the operational crack, randomly located smaller cracks of natural origin were revealed, while the roof continuity remained. After the third cycle, all cracks opened, the roof rocks were broken into large pieces of irregular shape, although the outline and integrity of the block between parallel technological cracks (multiple to the working width of the combine) remained.

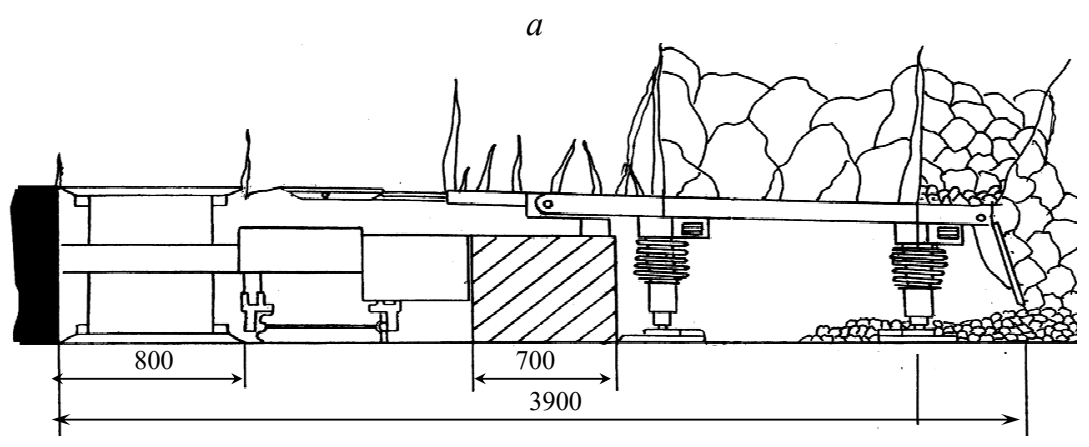

$b$

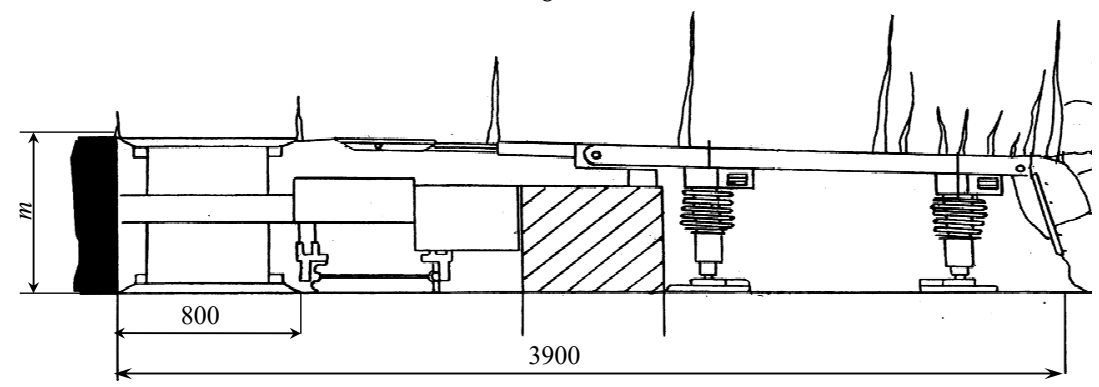

Fig. 1. The nature of crack formation in wall face equipped with a mechanized complex KMK97M, in the presence of argillite (a) and aleurolite (b) in the roof of the seam.

After the fourth cycle of coal mining, the roof rocks completely caved, partially spilled up into the working space of wall face, a rock pillow up to $10 \mathrm{~cm}$ thick formed on the ceilings. In the mined-out area, the immediate roof caved after each movement of the roof support.

In the presence of medium stable aleurolite in the immediate roof, crack formation occurred differently (see Figs. $1 \mathrm{~b}$ and $2 \mathrm{~b}$ ). After the combine passed through, a barely visible ( $1-2 \mathrm{~mm}$ wide) vertical technological crack parallel to the face line also appeared in the roof. The subsidence of the roof rocks along this crack did not exceed $5 \mathrm{~mm}$. After the extraction of the next strip of coal, the crack opened up to $5-8 \mathrm{~mm}$. Natural cracks appeared after excavation of the third strip. Before entering the mined-out area, the last block cracked along multidirectional natural cracks, while maintaining overall integrity. In the mined-out area, both in the wall faces equipped with KMK97M complexes and KD-80 complexes, the immediate roof most often collapsed after each movement of the support with blocks equal in working width of the combine $(0.8 \mathrm{~m})$. Behind the support, such blocks disintegrated into large units. Cases were recorded when the blocks were not destroyed but, forming a console, hung in the mined-out area. The length of the rock console was a multiple of the working width of the combine, i.e. $0.8 ; 1.6 ; 2.4 \mathrm{~m}$ and sometimes - reached $4.0 \mathrm{~m}$.

In all the studied wall faces, in the presence of medium stable aleurolite in the immediate roof, in the middle part of the mined-out area, shortening, caving in and inrushes of the roof 
between the face and the ends of the roof supports were often observed. Inrushes of roof rocks up to $1.5-2.0 \mathrm{~m}$ high were recorded at the end sections of the wall face, which is explained by the formation of zones of inelastic deformations around the extraction galleries. On average, the height of the inrushes was $0.2-0.5 \mathrm{~m}$, which contributed to the contamination of mined coal and an increase in its ash content by $4-10 \%$.

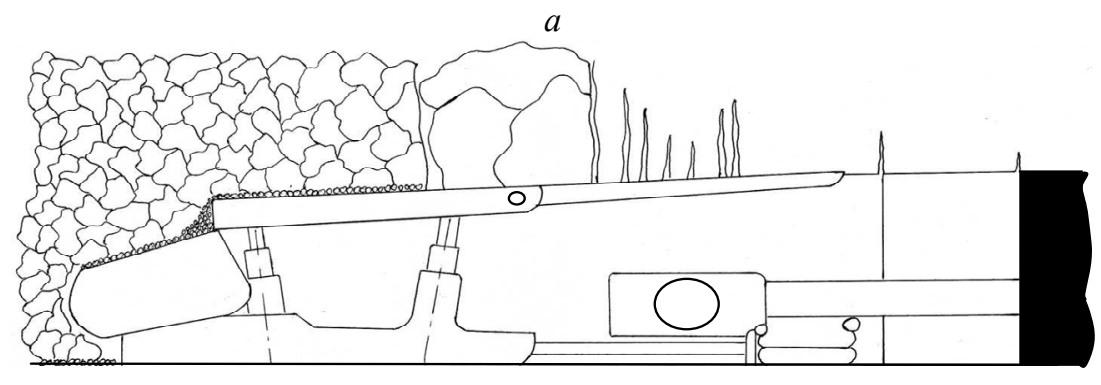

$b$

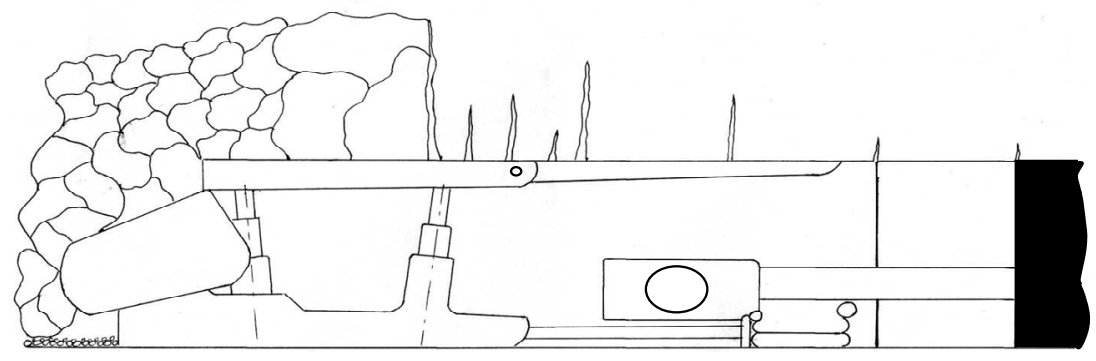

Fig. 2. The nature of crack formation in wall face equipped with a mechanized complex KD-80, in the presence of argillite (a) and aleurolite (b) in the roof of the seam.

\section{Study of the nature and magnitude of lateral rocks closure in wall faces}

Studies of the convergence of lateral rocks during the extraction of coal seams in wall faces were carried out at measuring stations located in the middle part of the wall face and at its end sections $[42,44]$. The first measuring stand was installed at a distance of $0.1 \mathrm{~m}$ from the face between the sections' ceilings, and the second behind the main conveyor at a distance of $1.2 \mathrm{~m}$ from the face between the same sections.

The indicator readings during coal mining were taken every 15 seconds. The countdown was carried out by stopwatch, which were previously verified and installed synchronously. When the combine approached the stand located at the face, the coal-face works stopped, the stand was rearranged behind the combine, and measurements continued. The location of the second stand made it possible to observe the convergence of the lateral rocks at the time of passage of the combine. For continuous control of convergence when the combine was moving away, two sections of powered roof support, between which a stand was installed, were not pushed to the face. Thus, a continuous measurement of the lateral rocks convergence over the entire period of the cycle of coal getting was carried out with reference to the distance to the combine.

As a result of the measurements, it was found that the closure rate of the roof and soil rocks in the middle part in the wall face until the combine approaches at a distance of up to $3 \mathrm{~m}$ remains constant (background) and equals $0.02-0.06 \mathrm{~mm} / \mathrm{min}$. When the combine comes closer than $3 \mathrm{~m}$, the closure speed begins to increase and reaches $0.8-1.2 \mathrm{~mm} / \mathrm{min}$ 
until the stand is rearranged. After rearranging the stand and continuing the movement of the combine, the convergence rate continues to grow rapidly and at a distance of $8-10 \mathrm{~m}$ from the combine is $1.6-1.8 \mathrm{~mm} / \mathrm{min}$. As the combine moves away from the measuring stand, the convergence rate decreases and reaches a background value at a distance of $25-$ $30 \mathrm{~m}(0.06-0.08 \mathrm{~mm} / \mathrm{min}$.). These values of the lateral rocks convergence were recorded at a seam extraction rate of $2.5-3.0 \mathrm{~m} / \mathrm{min}$.

With an increase in the combine feed rate for the coal extraction to $4.0-4.5 \mathrm{~m} / \mathrm{min}$. the closure rate of the roof and soil rocks in the wall faces increased sharply: before reaching the combine, it reached $1.5 \mathrm{~m} / \mathrm{min}$., after the passage of the combine, $1.9-2.2 \mathrm{~m} / \mathrm{min}$. Moreover, after the passage of the combine, the convergence rate sharply decreased and reached a background value at a distance of $15-20 \mathrm{~m}$.

An analysis of the results shows that the processes of displacement of the enclosing rocks in the excavation area occur at different rates. The convergence rate increases with decreasing distance to the combine and reaches its maximum value after its passage. The noted effect is explained by the lowering of the hanging rocks of the roof. The convergence rate of the lateral rocks increases with increasing excavation rate.

Rates and values of lateral rocks convergence were also measured at measuring stations located at the end sections of the wall face. As a result of studies, it was found that the rate and the total amount of closure of the lateral rocks at the end sections are $15-25 \%$ higher than in the middle of the wall face. This is due to the presence of areas of high rock pressure at the end sections of the wall face, formed as a result of the imposition of reference pressure areas from the wall face and development workings.

The total closure of the roof rocks in the working area of the studied wall faces was 30 $40 \%$ of the useful worked thickness of the seam. Such values were recorded at a movement rate of the breakage face line $1.3-1.9 \mathrm{~m} /$ day or $40-60 \mathrm{~m} / \mathrm{month}$. In the wall faces, where the movement rate of the breakage face line was higher than $60 \mathrm{~m} /$ day, the rocks closure at the border with the mined-out area was $25-30 \%$ of the useful worked thickness of the seam.

As a result of studies of the values and rates of roof and soil rocks convergence of in the wall face, it was found:

- The area of intensive closure of the lateral rocks is formed not only due to the coal extraction, but also due to the periodic unloading of the powered support sections, which moved after the seam excavation by the combine;

- The change in the values and rates of enclosing rocks convergence is significantly affected by the feed rate of the mining combine, namely, the higher the feed rate of the combine, the greater the values and the rate of rocks closure;

-In some cases, there was a surge in the convergence rate in front of the technological bench, which is explained by the crushing of the bench due to the high concentration of stresses in the coal mass;

- The rate of the rocks convergence o increases significantly when the combine approaches the niche at a distance of $7-8 \mathrm{~m}$, and at $1-2 \mathrm{~m}$ from the niche this parameter reaches its maximum values, which are $0.86-1.52 \mathrm{~mm} / \mathrm{min}$ depending on the feed rate of the combine;

- The total value of the lateral rocks convergence along the width of the working area decreases with increasing rate of wall face advance;

- At the end sections with a length of $15-25 \mathrm{~m}$, a more intense seam extraction, increased crack formation and greater values of roof and soil rocks convergence were observed. 


\section{Geomechanical changes in the rock mass and the earth's surface state in the territories of the coal mining regions}

The exploitation of coal enterprises leads to the change of geomechanical processes both in the subsoil and on the earth's surface: displacement of the roof rocks (on a steep incline and soles), intensive movement of underground waters and gases (methane), modification of seismic parameters of the rock mass, etc.

The development of the deformation and subsidence process of the earth's surface begins as soon as the roof is lowered over the mined-out area. The subsidence rate of the earth's surface depends on the seam thickness, the method of controlling the roof, the rate of the face advance. The process of displacement of the earth's surface is characterized by the total duration and period of dangerous deformations. The attenuation of the displacement process after intensive mining of seams at a depth of $600-700 \mathrm{~m}$ lasts at least 8 years.

Particularly dangerous for building on the earth's surface are the areas over the extinguished development workings of mines, which revealed cases of significant collapses of the roof rocks of the coal seam. After the workings of the mines are extinguished and the support is destroyed in them, the landslides of the rock collapses can be activated and create collapse funnels that can reach the surface. The subsidence area in the coal mining regions is more than $8000 \mathrm{~km}^{2}$, the subsidence depth of the earth's surface is $0.2-1.2 \mathrm{~m}$ on average (in some places it exceeds $5.0 \mathrm{~m}$ ).

Geomechanical processes are closely related to the mining and geological conditions and technologies of coal seams mining. Complex mining and geological conditions are the most potentially dangerous in the operation of mines. The most complex transformations occur while mining of workings in the conditions of geological disturbances (folded occurrence of rocks and the presence of discontinuous tectonic displacements in the minedout mass), as well as in the mining of the series of steeply inclined seams. In these circumstances, there is an abnormal development of shifting processes that causes significant changes in the state of the environment, waterlogging, and degradation of farmland.

As a result of many years of researches in the territory of the coal mining regions, it has been established that the mined-out area of wall faces and main mine workings, despite the considerable period of working out $(30-50$ years $)$, is not completely filled with rocks. Even at considerable depths, they have interstices of different sizes, which are washedaway as water appears. As a result, the rocks soaked in water begin to move, creating conditions for the sliding of the fractured rocks of overlying mined-out strata.

When studying the activation mechanisms of the displacement processes of the earth's surface it is established that the cause of the interstices' formation is:

- Uncontrolled collapse of rocks in mine workings;

- Complete or partial hang of roof rocks;

- Support remains in mine workings (wood, concrete, etc.);

- The stability of rocks in the workings depends on the degree of their metamorphism and the geological structure of the mined-out strata;

- Considerable fracture of the massif may remain and separate interstices can be formed in the mined-out strata and extinguished mine workings during a long period $(30-50$ years);

- Presence of water in extinguished workings under different pressure.

The condition of mine fields' sections, worked by wall faces, differs sharply from the status of the main mine workings, and is more favourable in terms of protection of objects on the earth's surface. The unfilled mined-out space in the main mine workings is always much larger than in the wall faces The interstices found in the mined-out area of the wall 
faces, with the average stability of the roof, in most cases, have a local character with an interstice height of up to $15-20 \%$ of the thickness of the coal seam. The main mining workings have higher percentages of filling $(50-60 \%)$, but their intersection area is usually $8-12 \mathrm{~m}^{2}$.

The state of the workings depends on the conditions in which they were: depth, level of filling with water, location in rocks of different stability, etc. The metamorphism of rocks significantly affects the stability of the mined-out strata, the condition of the mine workings, as well as the duration of storage of interstices in them.

The displacement of the rocks over the height of the mined seam is heterogeneous - in the lower part of the mined pillar the displacement is $1.3-1.5$ times smaller than in the upper one. From this it can be concluded that in the process of displacement of the roof rocks only the lower layers of the immediate roof are involved, and the height of the collapse is up to $1-2 \mathrm{~m}$ at a distance of $20-30 \mathrm{~m}$ from the breakage wall face (in the lower part of the roof practically does not collapse).

At present, in most coal mining regions, a significant number of subsidence of the earth's surface are recorded, which lead to the waterlogging of territories and the physical destruction of utilities, buildings and structures.

\section{Conclusions}

As a result of the research, the following conclusions can be drawn:

1. During underground coal mining, irreversible changes occur in the rock mass, enclosing the mined seam. These changes are the result of the collapse and subsidence of rocks over the coal-face working, the redistribution of stresses around it. Changes in the rock mass cause subsidence of the surface above the mine workings. Apart from the deformations from the influence of the coal-face working, additional displacements and deformations of the rock mass, the mined seam and the earth's surface arise, caused by the compression of the coal seam and the enclosing rocks under the influence of reference pressure.

2. As a result of the analysis of the displacement and deformation process of rocks and the earth's surface in the conditions of a coal deposit in the Western Donbas, it was found that to reduce the values of the subsidence of the earth's surface, it is necessary to use technologies that provide the minimum parameters of support zones, in addition to minimal displacements of roof rocks during mining. Such technologies may include technologies for separate excavation, mining of seams with chambers, as well as full stowing of the minedout area.

This work was supported by the Ministry of Education and Science of Ukraine under the project "Development of measures to improve the environmental situation and ecological safety in mining regions".

\section{References}

1. Pivnyak, G.G., \& Shashenko, O. M. (2015). Innovations and safety for coal mines in Ukraine. Naukovyi Visnyk Natsionalnoho Hirnychoho Universytetu, (6), 118-121.

2. Pivnyak, G.G., Pilov, P.I., Bondarenko, V.I., Surgai, N.S., \& Tulub, S.B. (2005). Development of coal industry: The part of the power strategy in the Ukraine. Mining Journal, (5), 14-18.

3. Belov, O., Shustov, O., Adamchuk, A., \& Hladun, O. (2018). Complex processing of brown coal in Ukraine: history, experience, practice, prospects. Solid State Phenomena, (277), 251-268. https://doi.org/10.4028/www.scientific.net/ssp.277.251 
4. Pivnyak, G., Dychkovskyi, R., Smirnov, A., \& Cherednichenko, Y. (2013). Some aspects on the software simulation implementation in thin coal seams mining. Energy Efficiency Improvement of Geotechnical Systems, 1-10. https://doi.org/10.1201/b16355-2

5. Savchuk, V., Prykhodchenko, V., Buzylo, V., Prykhodchenko, D., \& Tykhonenko, V. (2013). Complex use of coal of Northern part of Donbass. Annual Scientific-Technical Collection Mining of Mineral Deposits 2013, 185-191. https://doi.org/10.1201/b16354-34

6. Kirin, R. (2019). Statutory and regulatory requirements in the process of mineral mining in Ukraine. Review and analysis. Mining of Mineral Deposits, 13(2), 59-65. https://doi.org/10.33271/mining13.02.059

7. Vambol, S., Vambol, V., Kondratenko, O., Suchikova, Y., \& Hurenko, O. (2017). Assessment of improvement of ecological safety of power plants by arranging the system of pollutant neutralization. Eastern-European Journal of Enterprise Technologies, 3(10(87), 63-73. https://doi.org/10.15587/1729-4061.2017.102314

8. Shmandiy, V., Bezdeneznych, L., Kharlamova, O. at al (2017). Methods of salt content stabilization in circulating water supply systems. Chemistry \& Chemical Technology, 11(2), 242246. https://doi.org/10.23939/chcht11.02.242

9. Vambol, S., Vambol, V., Sundararajan, M., \& Ansari, I. (2019). The nature and detection of unauthorized waste dump sites using remote sensing. Ecological Questions, 30(3)3. https://doi.org/10.12775/EQ.2019.018

10. Khomenko, O., Kononenko, M., Myronova, I., \& Sudakov, A. (2018). Increasing ecological safety during underground mining of iron-ore deposits. Naukovyi Visnyk Natsionalnoho Hirnychoho Universytetu, (2), 29-38. https://doi.org/10.29202/nvngu/2018-2/3

11. Cherniaiev, O.V. (2017). Systematization of the hard rock non-metallic mineral deposits for improvement of their mining technologies. Naukovyi Visnyk Natsionalnoho Hirnychoho Universytetu, (5), 11-17.

12. Popovych, V., Kuzmenko, O., Voloshchyshyn, A., \& Petlovanyi, M. (2018). Influence of manmade edaphotopes of the spoil heap on biota. E3S Web of Conferences, (60), 00010. https://doi.org/10.1051/e3sconf/20186000010

13. Klimkina, I., Kharytonov, M., Zhukov, O. (2018). Trend analysis of water-soluble salts vertical migration in technogenic edaphotops of reclaimed mine dumps in western donbass (Ukraine). Environmental Research, Engineering and Management, 74(2), 82-93 https://doi.org/10.5755/j01.erem.74.2.19940

14. Kharytonov, M.M., \& Kroik, A.A. (2011). Environmental Security of Solid Wastes in the Western Donbas Coal Mining Region, Ukraine. Environmental Security and Ecoterrorism, NATO Science for Peace and Security Series C: Environmental Security, H. Alpaset al. (eds.), 129-138. https://doi.org/10.1007/978-94-007-1235-5_10

15. Gomelya, M.D., Trus, I.M., \& Radovenchyk, I.V. (2014). Influence of stabilizing water treatment on weak acid cation exchange resin in acidic form on quality of mine water nanofiltration desalination. Naukovyi Visnyk Natsionalnoho Hirnychoho Universytetu, (5), 100-105.

16. Kolesnyk, V., Kulikova, D., \& Kovrov, S. (2013). In-stream settling tank for effective mine water clarification. Annual Scientific-Technical Collection - Mining of Mineral Deposits 2013, 285-289. https://doi.org/10.1201/b16354-53

17. Shmandiy, V., Bezdeneznych, L., Kharlamova, O., Petrushka, K. et al. (2017). Methods of salt content stabilization in circulating water supply systems. Chemistry and Chemical Technology, 11(2), 242-246. https://doi.org/10.23939/chcht11.02.242

18. Zelenko, Y., Malovanyy, M., \& Tarasova, L. (2019). Optimization of heat-and-power plants water purification. Chemistry and Chemical Technology, 13(2), 218-223. https://doi.org/10.23939/chcht13.02.218

19. Adamenko, Y.O., Arkhypova, L.M., \& Mandryk, O.M. (2017). Territorial normative of quality of hydroecosystems of protected territories, Hydrobiological Journal, (53), 50-58. https://doi.org/10.1615/HydrobJ.v53.i2.50

20. Mandryk, O.M., Arkhypova, L.M., Pukish, A.V., Zelmanovych, A., \& Yakovlyuk, K. (2017). 
Theoretical and methodological foundations of sustainable development of Geosystems. IOP Conference Series: Materials Science and Engineering, (200), 012018. https://doi.org/10.1088/1757-899X/200/1/012018

21. Kvaterniuk, S., Pohrebennyk, V., Petruk, V., Kvaterniuk, O., \& Kochanek, A. (2018). Mathematical modeling of light scattering in natural water environments with phytoplankton particles. 18th International Multidisciplinary Scientific GeoConference SGEM2018, Informatics, Geoinformatics and Remote Sensing, 18(2.1), 545-552. https://doi.org/10.5593/sgem2018/2.1

22. Vasylkivskyi, I., Ishchenko, V., Pohrebennyk, V., Palamar, M., \& Palamar, A. (2017). System of water objects pollution monitoring. 17th International Multidisciplinary Scientifsc GeoConference SGEM2017 "Hydrology and water resources forest ecosystems", 17(3.3), 355362. https://doi.org/10.5593/sgem $2017 \mathrm{H} / 3.3$

23. Melnyk, L., Bessarab, O., Matko, S., \& Malovanyy, M. (2015). Adsorption of Heavy Metals Ions from Liquid Media by Palygorskite. Chemistry \& Chemical Technology, 9(4), 467-470. https://doi.org/10.23939/chcht09.04.467

24. Golinko, V.I., Cheberiachko, S.I., Yavors'ka, O.O., \& Tykhonenko, V.V. (2017). Assessment of protection level of dust respirators in terms of coal mines. Naukovyi Visnyk Natsionalnoho Hirnychoho Universytetu, (3), 95-100. https://doi.org/10.29202/nvngu

25. Gorova, A., Pavlychenko, A., \& Borysovs'ka, O. (2013). The study of ecological state of waste disposal areas of energy and mining companies. Annual Scientific-Technical Collection - Mining of Mineral Deposits 2013, 169-171. https://doi.org/10.1201/b16354-30

26. Kolesnik, V.Ye., Fedotov, V.V. \& Buchavy, Yu.V. (2012). Generalized algorithm of diversification of waste rock dump handling technologies in coal mines. Naukovyi Visnyk Natsionalnoho Hirnychoho Universytetu, (4), 138-142.

27. Gorova, A., Pavlychenko, A., Borysovs'ka, O., \& Krups'ka, L. (2013). The development of methodology for assessment of environmental risk degree in mining regions. Annual ScientificTechnical Collection - Mining of Mineral Deposits 2013, 207-209. https://doi.org/10.1201/b16354-38

28. Mormul, T.M., \& Terekhov Ye.V. (2017). Environmental and economic estimation of technological solutions in terms of land resource conservation in the process of open-cast mining. Naukovyi Visnyk Natsionalnoho Hirnychoho Universytetu, (3), 122-128.

29. Prokopenko, V.I., \& Litvinov, Yu.I. (2017). Environmental orientable imperative of developing the technology and excavation of horizontal fields. Naukovyy visnyk Natsionalnoho hirnychoho universytetu, (2), 51-57.

30. Gumenik, I.L., Lozhnikov, O.V., \& Panasenko, A.I. (2013). Deliberate dumping technology for mining reclamation effectiveness improvement. Naukovyi Visnyk Natsionalnoho Hirnychoho Universytetu, (5), 48-53.

31. Zadorozhnaya, G.A., Andrusevych, K.V., \& Zhukov, O.V. (2018). Soil heterogeneity after recultivation: ecological aspect. Folia Oecologica, (45), 46-52. https://doi.org/10.2478/foecol$\underline{2018-0005}$

32. Borisovskaya, Ye.A., \& Fedotov, V.V. (2014). Improvement of the method of danger class definition of coal-mining solid wastes. Naukovyi Visnyk Natsionalnoho Hirnychoho Universytetu, (3), 130-137.

33. Petlovanyi, M., Kuzmenko, O., Lozynskyi, V., Popovych, V., Sai, K., \& Saik, P. (2019). Review of man-made mineral formations accumulation and prospects of their developing in mining industrial regions in Ukraine. Mining of Mineral Deposits, 13(1), 24-38. https://doi:10.33271/mining13.01.024

34. Petlovanyi, M., Lozynskyi, V., Saik, P., \& Sai, K. (2018). Modern experience of low-coal seams underground mining in Ukraine. International Journal of Mining Science and Technology, 28(6), 917-923. https://doi.org/10.1016/j.ijmst.2018.05.014

35. Khomenko, O., Sudakov, A., Malanchuk, Z. \& Malanchuk, Ye. (2017). Principles of rock pressure energy usage during underground mining of deposits. Naukovyi Visnyk Natsionalnoho Hirnychoho Universytetu, (2), 35-43. 
36. Lozynskyi, V.G., Dychkovskyi, R.O., Falshtynskyi, V.S., Saik, P.B., \& Malanchuk, Ye.Z., (2016). Experimental study of the influence of crossing the disjunctive geological fault on thermal regime of underground gasifier. Naukovyi Visnyk Natsionalnoho Hirnychoho Universytetu, (5), 21-29.

37. Bondarenko, V., Symanovych, G., \& Koval, O. (2012). The mechanism of over-coal thin-layered massif deformation of weak rocks in a longwall. Geomechanical Processes During Underground Mining - Proceedings of School of Underground Mining, 41-44. https://doi.org/10.1201/b13157-8

38. Bondarenko, V.I., Kharin, Ye.N., Antoshchenko, N.I., \& Gasyuk, R.L. (2013). Basic scientific positions of forecast of the dynamics of methane release when mining the gas bearing coal seams. Naukovyi Visnyk Natsionalnoho Hirnychoho Universytetu, (5), 24-30.

39. Kolosov, D., Bilous, O., Tantsura, H., \& Onyshchenko, S. (2018). Stress-strain state of a flat tractivebearing element of a lifting and transporting machine at operational changes of its parameters. Solid State Phenomena, (277), 188-201. https://doi.org/10.4028/www.scientific.net/ssp.277.188

40. Belmas, I.V., Kolosov, D.L., Kolosov, A.L., \& Onyshchenko, S.V. (2018). Stress-strain state of rubber-cable tractive element of tubular shape. Naukovyi Visnyk Natsionalnoho Hirnychoho Universytetu, (2), 60-69. https://doi.org/10.29202/nvngu/2018-2/5

41. Lozynskyi, V., Saik, P., Petlovanyi, M., Sai, K., \& Malanchuk, Y. (2018). Analytical Research of the Stress-Deformed State in the Rock Massif around Faulting. International Journal of $\begin{array}{llll}\text { Engineering } \quad \text { Research } & \text { 7f }\end{array}$ https://doi.org/10.4028/www.scientific.net/jera.35.77

42. Buzylo V., Yavorskyy, A., \& Yavorsk'yy. V. (2012). Analysis of stress-strain state of rock mass while mining chain pillars by chambers. Geomechanical Processes During Underground Mining Proceedings of School of Underground Mining, 95-98. https://doi.org/10.1201/b13157-16

43. Shashenko, O.M., \& Kovrov, O.S. (2016). Comparative analysis of two failure criteria for rocks and massifs. Naukovyi Visnyk Natsionalnoho Hirnychoho Universytetu, (6), 54-59.

44. Soboliev, V., Bilan, N., \& Samovik, D. (2013). Magnetic stimulation of transformations in coal. Annual Scientific-Technical Collection - Mining of Mineral Deposits 2013, 221-225. https://doi.org/10.1201/b16354-41

45. Buzylo, V., Savelieva, T., \& Saveliev, V. (2012). Study of rock displacement with the help of equivalent materials using room-and-pillar mining method. Geomechanical Processes During Underground Mining - Proceedings of School of Underground Mining, 29-34. https://doi.org/10.1201/b13157-6

46. Babets, D.V., Sdvyzhkova, O.O., Larionov, M.H., \& Tereshchuk, R.M. (2017). Estimation of rock mass stability based on probability approach and rating systems. Naukovyi Visnyk Natsionalnoho Hirnychoho Universytetu. (2), 58-64.

47. Vladyko, O., Kononenko, M., \& Khomenko, O. (2012). Imitating modeling stability of mine workings. Geomechanical Processes During Underground Mining - Proceedings of School of Underground Mining, 147-150. https://doi.org/10.1201/b13157-26 